\title{
POTENTIAL OF THE CITY OF BELGRADE'S URBAN AREAS AND ESTABLISHMENT OF INSTITUTIONAL, STRATEGIC AND PLANNING FRAMEWORK FOR UTILIZATION OF RENEWABLE ENERGY SOURCES AND ENERGY EFFICIENCY WITHIN THE CITY OF BELGRADE
}

\author{
UDC 620.91(497.11 Beograd)
}

\author{
Marija Lalosevic $^{1}$, Mirko Komatina ${ }^{2}$, Marko Milos ${ }^{2}$, Filip Kanacki ${ }^{3}$ \\ ${ }^{1}$ Urban Planning Institute of Belgrade, Serbia \\ ${ }^{2}$ University of Belgrade, Faculty of Mechanical Engineering, Serbia \\ ${ }^{3}$ Netinvest, Serbia
}

\begin{abstract}
The paper analyzes the potential of renewable energy sources within the area of City of Belgrade, and explores the possibilities of their further implementation in the field of renewable energy sources and energy efficiency, in line with mandatory EU Directives. A synergetic approach has been proposed in the recommendations for the implementation of goals/targets and policies in the fields of renewable energy sources and energy efficiency in the City of Belgrade. They put an emphasis on the importance of implementation of the strategic documents of the City. Recommendations on have been provided regarding the required institutional preconditions that have to be met in order for these goals to be achieved, as well as urbanistic and building design-related measures/standards in achieving energy efficiency.
\end{abstract}

Key words: energy efficiency, renewable energy sources, strategies related to energy, sustainable development, the City of Belgrade

\section{INTRODUCTORY REMARKS, THE CONTEXT}

City of Belgrade Development Strategy [1], adopted by the City Hall in June 2011, established development vision, goals and operational tasks of the City Administration for the achievement of long-term development goals of Belgrade Region in various fields. One set of tasks and projects, foreseen for the period 2011-2016, within current institutional framework, has already been achieved, has commenced or has reached

Received August 26, 2015 / Accepted October 17, 2015

Corresponding author: Marija Lalosevic,

Urban Planning Institute of Belgrade, 30 Palmotićeva Str, 11000 Belgrade, Serbia

E-mail: marija.lalosevic@urbel.com 
certain level in the preparation for the realization. On the other hand, achievement of certain strategic priorities has not even commenced yet, as it is the case with those in the domain of the development of technical infrastructure and energy sustainability.

City of Belgrade Development Strategy states that, parallel to the development of conventional energy systems in Belgrade (remote/district heating system, gas pipelines and electro-energy systems), special attention will be paid to exploitation of renewable energy sources, such as geo-thermal energy, solar energy, wind energy and other, with the application of new technology solutions, through experimental and production facilities. This was concluded, based on the results of research and measuring, which showed existence of significant potential [2].

According to Draft Energy Sector Development Strategy of the Republic of Serbia up to 2025 with projections to 2030 [3], the basic targets in the field of renewable energy sources and energy efficiency are set to be: a more efficient utilization of Serbia's own renewable energy sources' potential; reduction of gas emissions with greenhouse effects and reduction of fossil fuels import. These are in line with „Europe 2020 - A strategy for smart, sustainable and inclusive growth" [4] which sets the goals through which achievement, over the upcoming decades, EU progress is foreseen as well as overcoming the existing economic and social issues. Europe 2020 sets goals related to climate changes and energy to be: greenhouse effects and CO2 emission reduction by 20\%, comparing to 1990 (even 30\% under favourable conditions); having $20 \%$ of total energy obtained from renewable sources, as well as increase of energy efficiency by $20 \%$ (EU's $20 / 20 / 20$ by 2020 ).

In Serbia, renewable sources, except potential of hydro energy, still make a small portion of energy balance, and practically comprise only biomass (firewood and insignificant volume of residue from agriculture and fruit production) and only mass energy consumers market. However, given the City of Belgrade's strategic development directions to increase the share of renewable energy sources (RES) and legal measures stimulating their implementation and also, granting of the special status to the energy producers that use RES, it should be expected that their share in the energy balance of City of Belgrade would increase.

Creating a favourable environment for the application and exploitation of renewable energy sources; clearly defining spatial and ecological criteria for the application of RES as well as regulatory framework (modification of taxation policy, assuring administrative and financial benefits and favourable market for promoting renewable energy sources development); utilisation of renewable energy sources in primary energy production and increasing the share of energy generated from renewable sources in energy balance; approximation to European norms, should be operational goals in the field of renewable energy sources.

Renewable energy sources are still more expensive than classical energy sources, due to either additional costs related to their preparation for utilization (biomass, communal waste), or high price of modern high-technologies (photovoltaic transformation of solar to electrical energy). Therefore, their utilization depends not only on its price, but on energy policy of one country and its stimulating measures, i.e. electrical energy market prices, which are the basic and essential drivers of investment in this sector. Having in mind the economic potential of Belgrade, as well as evident ecological problems, it is a realistic assumption that Belgrade will be in a better position than the rest of Serbia to introduce renewable energy sources with adequate stimulations from national and local levels, while keeping in mind that truly sustainable application of renewable energy sources cannot be, exclusively, based on subsidised prices of produced energy. 
The notion of improvement of energy efficiency in the construction of buildings (energy performance of buildings) refers to continuous and extensive set of activities which ultimate aim is to reduce all types of energy consumption, while assuring the same or better conditions for buildings' utilization and functionalities. The reduction in $\mathrm{CO}_{2}$ and other gas emissions are positive effects of reduction of non-renewable energy source (fossil fuels) consumption and of renewable energy sources usage, which further contribute to environmental protection, global warming reduction and sustainable development of a city.

Energy efficiency can be achieved by using more efficient systems for air and water heating, ventilation, air conditioning and lighting, including usage of waste heat and renewable sources, as well as by careful and systematic urbanistic planning and architectural design which contribute to improved energy performance of the buildings.

Over the past years, Serbia, like many other countries of Central and Eastern Europe, has taken initial steps towards establishing a system for organized improvements in energy efficiency on energy consumption side. This complex process encounters numerous objective and subjective obstacles, and only through systematic and synergetic approach to this problem a significant contribution towards improvements in energy efficiency indicators can be made. Therefore, it is necessary to fulfil all the institutional and regulatory requirements in order to assure sustainability and purposefulness of the entire process. At the same time, special attention needs to be paid to the consciousness of the energy consumers, given that rational energy consumption rests on the principles of reasonable consumption, which is directly related to the consumers' behaviour.

\section{Regulatory Obligations OF THE REPUbliC OF SERBIA RELATED TO THE IMPROVEMENT IN EE}

Practical application of Energy Performance of Buildings Directive (EPBD) [5][6] in the Republic of Serbia, has commenced with the adoption of the Law on Planning and Construction [7] which introduced certification of energy characteristics of a building (energy passport) as an obligation and an integral part of technical documentation, which needs to be submitted with the Request for issuing a building use permit. By adopting a Rulebook on energy efficiency of buildings [8] and Rulebook on conditions, content and procedures for issuing certificate on Energy performance of buildings [9], the process of certification of energy performance of buildings is regulated in details on the entire territory of the Republic of Serbia.

Further, it is of immense importance for the Republic of Serbia to adopt a unified methodology for calculation of energy performance of the buildings that will be applied at the national level (through the usage of, at the moment missing, national software). It is also important to mention the importance of enforcement of by-laws, in practice, which contain all relevant data and technical requirements for the design of buildings and electromechanical systems that need to assure comfortable environment with minimal energy consumption. Special attention needs to be paid to urbanistic planning, which, only in singular cases, observed the: principles of green (passive, bioclimatic) architecture, energy efficiency improvements and essentially sustainable urbanistic and strategic planning. 


\section{JURISDICTIONS, ENFORCEMENT AND SOURCES OF FUNDING IN THE REPUBLIC OF SERBIA AND THE CITY OF BELGRADE}

The institutions responsible for all energy efficiency related issues, energy development and renewable energy sources on the territory of the Republic of Serbia are: the Ministry of Energy and Mining of the Republic of Serbia (which is also in charge of defining strategies and targets in this area), The Ministry of Construction, Transport and Infrastructure of the Republic of Serbia, The Ministry of Agriculture and Environmental Protection of the Republic of Serbia and the Energy Agency of the Republic of Serbia. The Serbian Energy Efficiency Agency (SEEA), which existed from 2002 until 2013, was created due to the strategic need for the improvement of conditions and measures for economical usage of energy and energy sources. It was established in 2002, as a part of the reform process within the energy sector, with financial support from the European Union, through European Agency for Reconstruction (CARDS programme). SEEA was in charge of performing specific tasks related to the promotion of the importance of energy efficiency, management of programmes and projects aimed at rationalization of utilization of energy and increased utilization of RES, as well as other tasks defined by the relevant Law. Unfortunately, this institution, despite its strategic importance, was closed.

The City of Belgrade, within its structure, does not have an adequate institution for monitoring, control and support to the projects and renewable energy sources utilization and energy efficiency in the city of Belgrade.

Investments in renewable energy sources have not received yet significant attention in the economic and energy development of the Republic of Serbia and the City of Belgrade. The reasons are low price of electrical energy; insufficient knowledge (of both experts and public) on advantages of renewable energy sources' usage; insufficient number of comparative analyses on investment return of introduction of these technologies and their effects on ecology; as well as relatively high initial investments.

The necessity to make large investments usually inhibits growth of active utilization of renewable energy sources and their systematic application. Over the last years, the Republic of Serbia introduced a set of by-laws in support to production of electrical energy from renewable energy sources and co-production of electrical and thermal energy, in line with the Law on Energy of the Republic of Serbia [10]. Through these by-laws, potential investors are stimulated to invest in development and utilization of RES in the Republic of Serbia.

Directive on supporting measures for privileged electrical energy producers defines, in more details, means and conditions under which energy facilities investors, regardless of installed capacities, can realize economic and financial benefits, if they use renewable energy sources. Major shortcoming of this Directive, as well as other by-laws, is the lack of guarantees in pre-investment period, for the realization of beneficial prices for electrical energy produced in such way. It also states the reasons why financing of banking sector is not sufficiently established and implies an insufficiently developed economic model. Specific difficult circumstances are related to wind and solar energy, because of the limited capacity of the final energy produced from them that can be subsidized.

According to the draft Energy Sector Development Strategy of the City of Belgrade [11], available energy potential that renewable energy sources hold is estimated at about $8.36 \%$ of demanded primary energy at the City of Belgrade territory. The level and dynamics of renewable energy sources utilization until 2030, will heavily depend on the realization of government and/or local-self-government's supporting measures.

Another ways of stimulating exploitation of renewable energy sources are through the application for EU funds. EU finances actions and projects related to climate changes for 
the improvement of energy efficiency principles implementation, environment protection and utilization of renewable energy sources in developing countries. EU Member States, have committed to donate 7.34 billion Euros in the period 2010-2012 as a part of this fast-start projects funding. Beyond 2012, EU continued to finance developing countries. In mid and long term, developed countries will, jointly, mobilize 100 billion USD, by 2020, and EU remains committed to that goal. This money should come from various sources, yet its availability greatly depends on the transparency in project implementation within a developing country [12].

\section{RENEWABLE ENERGY SOURCES - RESEARCH ON PROJECTIONS OF POTENTIAL OF URBAN AREA OF THE CITY OF BELGRADE}

Projection of the potential of urban area of the City of Belgrade is presented per type of renewable energy source.

\section{Biomass}

Biomass is applied in production of electrical and thermal energy (in low-power cogeneration plants), biogas and biodiesel, and as such, it represents significant energy potential of the City of Belgrade's territory. Next to firewood, which is a dominant renewable energy source, wood residue from forests, parks and green areas, residues from agriculture, fruit and vegetable production and viticulture, hold energy value too. By planned afforestation of Belgrade and growing forests for special purposes (protective and energy related), the energy potential of wood residue and firewood could be doubled by 2030 , with a share in primary energy production of between 4.5 and $5 \%$ [11].

In line with EU policy and goals defined in Energy Sector Development Strategy by 2015 and Strategy Implementation Programme, Belgrade will be obliged to create preconditions for maximal exploitation of all renewable energy sources, and even solid waste biomass.

\section{Geo-thermal energy}

Geothermal exploration [13], conducted on area covered by Master Plan of Belgrade (territory of approximately $52.570 \mathrm{ha}$ ) indicated significant energy potential of underground water resources. Overall energy potential of underground waters, in the City of Belgrade proper territory is about 1.200 MW. That power is sufficient to satisfy, almost all basic energy needs of the City, which places this resource among the most potent and strategic ones.

Perspective locations for the intensive utilization of this resource are: Novi Beograd, Zemun, Avala and Visnjica, where temperature of thermal waters could exceed $80 \mathrm{C}$.

At the territory of Belgrade, next to favourable conditions for exploitation of geothermal energy from the reservoirs of hydro geothermal systems, favourable are conditions for exploitation for geothermal energy from dry rocks, i.e. geosonde.

According to energy efficiency principles and laws of physics, it is appropriate to use thermal energy for heating, because the energy losses, which usually occur in conversion processes (thermal to electric, over mechanic, etc.) are eliminated. It can be used for cooling, in the new buildings, which prevents peaks in electrical energy consumptions that are evident in the recent years. 
A modest share of this resource has been estimated at annual level to $270 \mathrm{GWh}$ (or $0.5 \%$ of primary energy) in 2030 [11].

After communal waste and biomass, geothermal energy is the biggest renewable energy source that can be exploited in Belgrade, should favourable conditions be created. By installing micro-cogeneration systems with the application of thermal pumps (even tri-generation), and exploitation of energy from rocks at greater depths, in Belgrade, it is possible to generate energy (thermal and electric) with over $5 \%$ of share in energy balance.

\section{Solar energy}

Overall solar energy that the City of Belgrade's territory receives every year is about $5200 \mathrm{~kW} / \mathrm{m} 2$, meaning that Belgrade has extremely favourable conditions for exploitation of solar energy. Next to direct exploitation of solar energy through active systems, passive exploitation of solar power is possible in Belgrade as well. It is interesting because it is more affordable (economically and energy-related) for heating, especially in the zones with low population density. Also, over the past years, photovoltaic technologies for conversion within special collectors or throughout building-in special materials into the walls and roofs of buildings, have been developed. So, it can be expected that exploitation of solar energy in this manner will be more and more applied in the urban areas of the City of Belgrade.

Energy efficiency rests on the principles of rational energy consumption, which tackles economical aspects as well. Thus it is important to emphasize that photovoltaic collectors which produce electrical energy from solar energy, should be used for supplying with power appliances which are within some other installations (such as circular pumps within heating systems), or electrical appliances with small power consumption, rather than dominant power users, such as ovens, stoves or boilers, due to their high price.

Generally speaking, a significant share of this renewable energy source in satisfying the power needs of Belgrade citizens, cannot be expected in the near future. However, with an increase in collective and individual living standards, as well as with the adoption of obligations at EU accession, the adequacy of solar energy could be reconsidered, and an increase of its share in energy balance at the City of Belgrade territory could be expected.

\section{Wind energy}

Having in mind that the territory of the City of Belgrade is exposed to a specific type of wind - Kosava, one could say that the city has a significant wind energy potential.

Beside typical problems faced with at the installation of large wind-power plants (noise, transport, effects to electro-energy system), potential of wind is extremely unpredictable in urban areas and depends on morphology and altitude of the location in which it is planned to be exploited. In urban areas, it is desirable to position small wind turbines (up to $10 \mathrm{~kW}$ installed power) on the top of the tallest building(s) and it should be sufficiently lifted from the installation point, to minimize undesirable turbulence effects. The advantage that wind has over solar energy is its permanent potential (it can blow during the day and night) while its disadvantage rests in its unpredictability. Due to the nature of conversion of kinetic to electric energy, small wind generators have mechanical parts which need to be maintained, and, important to mention, produce noise. Unless carefully installed on the top of residential buildings, residents can suffer real disturbances, so special attention needs to be paid to this aspect.

In present conditions, it is estimated that this energy can be utilized for the production of $60 \mathrm{GWh}$ of electrical power, each year, at maximum. Total share in overall energy 
production, of this potential, is forecasted to $0.5 \%$ in 2030 [11] and not even multiple increase in capacities of wind generators (that would be possible in favourable economic environment), would improve the energy balance.

\section{Communal waste}

Among all renewable energy sources in Belgrade, communal waste has the biggest energy potential, with $2000 \mathrm{GWh}$ per year, which makes $45 \%$ of potential of all renewable energy sources, and can contribute about $4 \%$ in primary energy production balance [11]. However, for this renewable energy source to be exploited to its maximum, it is necessary to introduce a modern waste management system. For the construction of energy facilities that use communal waste, significant investments are needed, especially for the environmental protection.

Energy potential of solid waste is in its combustible part and landfill gas released from its decomposition. The quantities of solid waste collected and taken out of the city of Belgrade territory are 1,528 t per day or 557,720 t per year, at the moment, with average thermal value of $8 \mathrm{MJ} / \mathrm{kg}$ [14]. It is expected that these values will increase, and the projections for 2024 are $1.35 \mathrm{~kg} /$ citizen per day, or $615,755 \mathrm{t}$ per year. National programme of environment protection predicts that, at the territory of Belgrade, the recycling rate will reach $25 \%$ beyond 2015 . Going towards that target, waste management should be focused on closing the existing non-sanitary landfills in Vinca, and constructing the Centre, at the location next to the existing landfill (with landfill gas utilization facilities). In central city municipalities, recycling of waste should be centrally organized. With the adoption of the Plan for detailed regulation of sanitary landfill Vinca [15], urbanistic preconditions have been met, while the Plan was voted for one of the most ambitious city projects in 2015 , i.e. one of the most important projects for the City.

Further efforts are needed in the implementation of the Analysis of the suitable locations for the construction of recycling centres - yards [16] through detailed regulation plans. That would contribute to strengthening positions, importance and essence of these facilities, which make the key infrastructure for enabling the development of primary selection of waste and assuring reliable inflow of raw material for further processing for the City of Belgrade.

\section{TheORETICAl CONTEXT - StRATEgic PRIORITIES IN THE FIELD OF RENEWABLE ENERGY SOURCES AND ENERGY EFFICIENCY AS SET IN THE DEVELOPMENT STRATEGY OF THE CITY OF BELGRADE}

Development Strategy of the City of Belgrade is one of the most important strategic documents, and it gives directions for planning and programming, but sets commitment as well, to achieve sectorial strategic priorities in given timeframe. For all priority projects, the Strategy foresees 2016 as the end date for their completion and puts sole responsibility on the City of Belgrade. In the domains of technical infrastructure and energy sustainability, the Development Strategy of the City of Belgrade has identified priority projects whose realization, unfortunately, has not commenced yet [17]. Dedicated and persistent efforts will be needed to realize these projects over the upcoming period. The next evaluation of the Strategy implementation, foreseen for 2016, inclusive of recommendation for the next 5 year period, should insist on the implementation of the following priority projects, while their domain should be expanded to include other projects in this field, as well. 
- "Intensive exploitation of resources of renewable energy sources" is a project that should encompass a series of sub-projects aiming to establish renewable energy sources potential, their locations throughout the city as well as projects related to specific utilization of renewable energy sources. Well-conceived utilization of these resources could, certainly, contribute to significant reduction of demand for fossil fuels and import dependency.

- "Increasing energy efficiency" is a project that aims at adoption of various measures and support activities that would contribute to rational consumption and production of all types of energy. Through the realization of individual projects, energy efficiency in the buildings, households, public lighting and public buildings would increase, which should be built or reconstructed, for the first time, in line with the Directives.

- "Education on energy efficiency" is a project through which permanent awareness raising would be supported on the importance of energy, necessity and possibilities of energy efficiency. Through the project, wide target audience should be reached, with special emphasis on stakeholders that have responsibility of monitoring energy consumption at various levels.

- "Establishment of city funds for energy efficiency" is a project that would aim at implementation of measures that contribute to increase of energy efficiency within group and individual entities.

- "Development of Belgrade's energy information system (BEIS)" is a project that should continuously monitor energy flows within the City of Belgrade territory in all of its aspects, in order: to provide data, whose analysis could prevent disturbances in energy supply; to support planning process and energy management; to define measures which contribute to reduction of energy losses; to optimize consumption of all types of energy and reduce environmental pollution. This information system should be a modern, integrated, open and interoperable WEB application, in line with EU and international standards, which would support energy resource management in a sustainable way, based on collection, analysis, archiving and distribution of precise data and information.

At the city level, new priority projects should be introduced, foremost, a project that focuses on improvement of existing City of Belgrade construction fund. Its purpose would be to support implementation of energy efficiency measures to rational maximal extent and conversion to from classical systems to using renewable energy sources in existing buildings in urban area of the City of Belgrade. Research phases could be territorially organized by city's municipalities, with special focus on achieving savings, users' comfort and potential reduction of classical fossil fuels usage, with the usage of renewable energy sources. Public facilities (schools, kindergartens, hospitals, prisons...) should be the first exposed to the measures and participate in the implementation of these projects.

\section{RECOMMENDATIONS FOR THE IMPROVEMENT OF ENERGY EFFICIENCY OF THE URBAN AREA OF THE CITY OF BELGRADE}

In the field of energy efficiency, special attention should be paid to the application of urbanistic and architectural parameters that contribute to energy efficiency of buildings. Important energy parameters are form and orientation of a building that determine its exposure to outer climate influences (temperature, wind, humidity, and insulation). 
Favourable natural characteristics of urbanistic position and location should be utilized, while negative effects should be protected against to their maximum extent. By choosing proper shape, orientation and position for a building, as well as making the proper selection of construction and protection materials, good energy performance of a building can be achieved.

In the design and construction of planned buildings at the City of Belgrade territory, the following measures of energy efficiency should be applied:

- Use new technical and technological solutions as much as possible, in order to achieve energy efficient construction and usage of the building;

- In the design stage, it is necessary to pay attention to orientation and functional concept of a building, in order to capitalize on nature and natural resources at the building location, primarily solar and wind energy, as well as the surrounding greenery;

- Design thermal zoning of a building, i.e. group rooms with similar functions and inner temperatures, e.g. home utility rooms should be oriented to the North;

- Tend to keep building a compact one, to prevent greater energy loss, i.e. chose a design of a building that would have a better energy efficient ratio between the surface and the volume of building shell with regard to the climate factor and purpose of the building;

- It is necessary to assure maximized exploitation of natural lighting, as well as to use passive thermal energy gains during the winter season, and protect against overheating during summer by using adequate shading;

- Optimize window size to reduce energy loss, while allowing sufficient light into the rooms;

- Protect parts of the buildings that are exposed to sunlight during the summer with greenery and other measures;

- Design "fifth facades", such as green roofs, whenever possible;

- In the design, plan for a natural ventilation system (ventilation channels, windows, doors, other construction openings) to reduce heat loss during the winter and overheating during the summer periods;

- Depending on the purpose of a building, foresee adequate thermo-mass to achieve thermal comfort in the winter and summer periods - to increase thermal inertia of a building. It is necessary to apply high quality thermal isolation to entire building, in line with standards and regulations in force;

- Building structure and shell should be designed to assure maximal usage of passive and active solar systems;

- When using rainfall, underground waters and wastewaters for watering, external usage, heating and cooling of the building, technical facilities (reservoir and pump system) used, if underground, should not be taken into calculation of land occupancy index;

- Use potential of renewable energy sources at the location - solar energy, energy of underground waters, wind and others by applying greenhouses, photovoltaic panels, solar collectors, thermal pumps, etc. Thermal pumps, within these systems can be used for heating during the winter and for cooling during the summer months, thus assuring pleasant and balanced climate throughout the entire year. Photovoltaic panels should be used to maximal extent for production of electrical energy;

- When designing thermo-technical systems, all elements of heating, cooling and ventilating should be foreseen with a high level of usability; 
- Central heating systems should be designed and built-in, in such manner to enable central and local regulation and measuring the energy consumption for heating;

- Use energy efficient lighting elements;

- Take care of economical consumption of all forms of energy, regardless of their renewability;

- Use construction materials from the environment;

- Continuously raise ecological awareness and ethics among investors and citizens about the importance and necessity of energy efficiency in broader sense;

- Sort recyclable waste for further processing;

- Street furniture that requires electrical energy, should be planned as self-sustainable in terms of energy, by installing photovoltaic panels of small dimensions or similar equipment that will use RES to produce and secure electrical energy for public lighting poles, advertising panels, billboards, bus stops, Wi-Fi spots, etc.

Beside new buildings, special attention needs to be paid to implementing energy efficiency measures in the existing buildings, by acting on both outer layers and building shells, in the sense of improving their thermal characteristics, through which greater comfort for users would be achieved as well as additional savings in the energy consumption. It would also require attention to be paid to inner installations, in the sense of converting to the usage of renewable energy sources, which would reduce the load on existing thermal plants. Proposed measures for achieving energy efficiency in the existing buildings should be applied to maximal extent, which the object and location's conditions would allow for.

\section{CONCLUDING REMARKS AND RECOMMENDATIONS FOR THE IMPLEMENTATION OF GOALS AND POLICIES - SYNERGIC APPROACH}

Business environment, in which energy sector in Serbia will operate in the future, changes very fast and requires new concepts and policies to secure energy supply. Structural changes in economy, development of high technologies, as well as increasing life standard of citizens, make a community, as a whole, more sensitive to energy crisis. Thus, it is important to explore new concepts that will reduce risks of disturbances in energy supply, take care of environment, contribute to sustainable development and shift focus to maximal utilization of potential of renewable energy sources in the local surrounding.

Renewable energy sources become inevitable factor worldwide in planning and research, as well as in application. One of the important tasks of utilization of renewable energy sources is to enable local users' greater energy independence, i.e. independence from national and regional power supply and great distribution centres. In line with that, it is mandatory that the City of Belgrade, through its local self-governance and all stakeholders relevant for the city development, puts the biggest effort in increasing importance of energy, utilization of renewable energy sources and energy efficiency in households and industry, and thus contribute to the reduction in consumption of all types of energy, especially electric (in the residential buildings, transport, industry and services). Potential of renewable energy sources in local surrounding should be maximally used in order to achieve greater energy independence and sustainability.

The fact is that, at this moment and circumstances, utilization of renewable energy sources potential in the City of Belgrade is more related to the tempo of solving ecological problems of Belgrade, and regulations and laws on environmental protection, than to its energy needs, sustainable development and achievement of economical energy production. Therefore, public 
and professional community should be permanently educated and investments should be made, so the utilization of renewable energy sources and application of energy efficiency concepts and not being delayed any longer due to lack of information or indifference.

Efforts toward improvement of energy efficiency in the City of Belgrade need to be based on: introduction of energy efficiency principles to all levels of planning, design, construction and utilization of buildings and infrastructure; reduction of thermal energy consumption in the system of Belgrade's thermal power plants and industrial processes; reduction of losses in the thermal energy distribution; increase efficiency of thermal energy production within existing facilities, as well as replacement of less efficient ones; establishment of regulations on energy planning and consumption at city level to assure that all Belgrade municipalities have a plan on energy supply, distribution and consumption within their territories; uniform availability of energy infrastructure to all Belgrade districts.

Creation of a favourable environment for the application of renewable energy sources, clear definition of spatial, urbanistic and ecological criteria for application of renewable energy sources and energy efficiency, regulatory framework (changes in tax policies, assuring administrative and financial subventions and favourable market for promotion of renewable energy sources development), renewable energy sources exploitation in primary energy production and increase of energy from renewable energy sources and approximation to European norms are operational goals in the field of renewable energy sources and energy efficiency. Belgrade, as the capital of the Republic of Serbia, has to start, first, with introduction of changes and implementation of these strategically important goals.

The entire complex system of the City of Belgrade, with numerous and more complex sub-systems and interdependencies, require a highly organized management of the City. Management tools: information system, budget, tax system, land, communal, residential and other policies and instruments, need to be modernized and synchronized at higher level than the current one.

In order to monitor realization of the Development Strategy of Belgrade in adequate manner, all development parameters need to be controlled, knowledge and ideas need to be collected, and strategic priorities in the field of renewable energy sources and energy efficiency need to be set and regularly monitored, control and support projects and utilization of renewable energy sources and energy efficiency in the City of Belgrade, an Agency for renewable energy sources and energy efficiency, as well as Secretariat for renewable energy sources and energy efficiency need to be established. This would further contribute to the improvements in organizational structure of the city of Belgrade, which would have expert and technical capacity to assure efficient implementation of laws, by-laws, regulations and rulebooks in the fields of renewable energy sources and energy efficiency and establishment of modern and efficient mechanisms for quality control of projects and their implementation.

Sustainable development is a concept of development that satisfies current needs, but takes into consideration the needs of the future generations. Therefore, improvements in energy efficiency is one of the pre-requisites for sustainability of society as a whole. Due to the fact that there is a great economic potential in energy efficiency and renewable energy sources, and that realization of programs and projects in these fields, with application of modern technologies, has not only energy, but positive ecological, economic and social effects as well, the support, in this sense, has to be provided over a longer period, and followed by tax and financial incentives, regulatory requirements, investments in education and research as well as strengthening of institutional capacities of the City of Belgrade. 


\section{REFERENCES}

1. „Strategija razvoja grada Beograda“(,Službeni list grada Beograda“ br. 21/2011), Beograd, 2011.

2. „Strategija razvoja grada Beograda“ (,Službeni list grada Beograda“ br. 21/2011), Poglavlje „Razvoj tehničke infrastrukture i energetska održivost“, Podpoglavlje „Razvoj i primena obnovljivih izvora energije“, Beograd, 2011.

3. „Strategija razvoja energetike Republike Srbije do 2025. godine sa projekcijama do 2030. godine predlog", Beograd, 2015.

4. „Europe 2020 - A strategy for smart, sustainable and inclusive growth“, European Commission, Brussels, 2010.

5. „Energy Performance of Buildings Directive“ (Directive 2002/91/EC, EPBD), The European Parliament and the Council of the Europian Union, December 2002.

6. „Energy Performance of Buildings Directive - Recast“ (Directive 2010/31/EU, EPBD), The European Parliament and the Council of the Europian Union, May 2010.

7. „Zakon o planiranju i izgradnji“ („Službeni glasnik Republike Srbije“ br.72/2009, 81/2009, 64/2010, 24/2011, 121/2012, 42/2013, 50/2013, 98/2013, 132/2014 i 145/2014).

8. „Pravilnik o energetskoj efikasnosti zgrada“ (,Službeni glasnik RS“ br. 61/2011).

9. „Pravilnik o uslovima, sadržini i načinu izdavanja sertifikata o energetskim svojstvima zgrada“ (,Službeni glasnik RS“ br. 69/2012).

10. „Zakon o energetici Republike Srbije“ (,Službeni glasnik RS“ br. 145/14)

11. "Strategija razvoja energetike grada Beograda - predlog“, Grad Beograd, Sekretarijat za komunalne i stambene poslove, Uprava za energetiku, Beograd, 2010

12. http://ec.europa.eu/clima/policies/finance/international/index_en.htm (08.07.2015. godine)

13. Studija „Detaljna istraživanja subgeotermalnih podzemnih vodnih resursa grada Beograda - potencijal, mogućnosti korišćenja i energetska valorizacija“, Univerzitet u Beogradu, Rudarsko-geološki fakultet, Beograd, 2012.

14. „Lokalni plan upravljanja otpadom grada Beograda 2011-2020“ („Službeni list grada Beograda“ br. 28/2011), Beograd, 2011.

15. „Plan detaljne regulacije sanitarne deponije Vinča“ („Službeni list grada Beograda“ br. 17/2015), Beograd, 2015.

16. „Analiza lokacija za izgradnju reciklažnih centara - dvorišta“, Urbanistički zavod Beograda, Beograd, 2013.

17. „Strategija razvoja grada Beograda“ („Službeni list grada Beograda“ br. 21/2011), Poglavlje „Strateški prioriteti 2011-2016“, Beograd, 2011.

\section{POTENCIJAL URBANOG PODRUČJA GRADA BEOGRADA I USPOSTAVLJANJE INSTITUCIONALNOG, STRATEŠKOG I PLANSKOG OKVIRA UPOTREBE OBNOVLJIVIH IZVORA ENERGIJE I ENERGETSKE EFIKASNOSTI U GRADU BEOGRADU}

$U$ radu su analizirani potencijali obnovljivih izvora energije područja Grada Beograda $i$ istražene mogućnosti njihove dalje implementacije $u$ oblasti obnovljivih izvora energije $i$ energetske efkasnosti, u skladu sa obavezujućim dirketivama EU. Predložen je sinergijski pristup u preporukama za implementaciju ciljeva i politika Grada Beograda u oblasti obnovljivih izvora energije $i$ energetske efkasnosti, sa naglaskom na važnosti implementacije strateških dokumenata grada. Dati su predlozi potrebnih institucionalnih preduslova za realizaciju ciljeva u oblasti kao $i$ urbanističke i projektantske mere u postizanju energetske efikasnosti.

Ključne reči: energetska efikasnost, obnovljivi izvori energije, energetske strategije, održivi razvoj, Grad Beograd 